Graham H. McMorland MB CH B FRCPC,

M. Joanne Douglas MD FRCPC, Wayne K. Jeffery M SC,

Peggy L. E. Ross MD в SC(Med) FRCPC, James E. Axelson PH D,

James H. K. Kim MD FRCPC,

David R. Gambling MB BS FRCPC,

Kerri Robertson MD,

\title{
Effect of pH-adjust- ment of bupivacaine on onset and duration of epidural analgesia in parturients
}

Previous studies have reported that elevation of the $\mathrm{pH}$ of local anaesthetics is associated with enhanced quality and duration of block. This study investigated the effect, on time to anset and duration of analgesia, of $\mathrm{pH}$ adjustment of 0.25 per cent bupivacaine immediately prior to injection into the epidural space in parturients. Addition of 0.1 $\mathrm{ml}$ of 8.4 per cent sodium bicarbonate to $20 \mathrm{ml}$ of 0.25 per cent bupivacaine consistently raised the $\mathrm{pH}$ of the local anaesthetic from 5.65 to 7.26 (mean values).

Thirty parturients received an epidural injection of $8 \mathrm{ml}$ of $\mathrm{pH}$-adjusted 0.25 per cent bupivacaine and a control group of 30 parturients received $8 \mathrm{ml}$ of the standard commercial preparation of 0.25 per cent bupivacaine. Elevation of the $\mathrm{pH}$ of the local anaesthetic significantly increased the speed of onset of analgesia from 6.0 minutes to 3.2 minutes and the duration of analgesia was significantly lengthened from 79.4 minutes to 96.5 minutes. There was no significant influence on time to peak effect, nor on mean maternal plasma levels of bupivacaine.

\section{Key words}

ANAESTHESIA: obstetric, epidural; LOCAL ANAESTHETICS: bupivacaine.

From the Department of Anaesthesia, Faculty of Medicine and Faculty of Pharmaceutical Sciences, University of British Columbia and Grace Hospital, Vancouver, British Columbia.

Presented in part at the Annual Meeting of the Society for Obstetric Anesthesia and Perinatology, Washington, D.C., May, 1985.

Supported by a grant from Winthrop Laboratories (Division of Sterling Drug Limited).

Address correspondence to: Dr. G.H. McMorland, Department of Anaesthesia, Grace Hospital, 4490 Oak Street, Vancouver, B.C. V6H 3 V5.
In 1960, Loder ${ }^{1}$ reported that addition of dextran to local anaesthetic solutions resulted in a significantly prolonged duration of intercostal nerve blocks. Subsequent attempts to confirm Loder's observations yielded inconsistent findings, with some groups finding that the duration of block was markedly increased ${ }^{2,3}$ while others failed to demonstrate any prolongation of block. ${ }^{4-6}$ Rosenblatt ${ }^{7,8}$ reported that the $\mathrm{pH}$ of the dextran used in one local anaesthetic study was more alkaline than that of the dextran used in a subsequent study. The dextran with the more alkaline $\mathrm{pH}$ was associated with a longer duration of block, when mixed with bupivacaine, than the dextran with the lower $\mathrm{pH}$. Mixtures of bupivacaine with other alkaline compounds, such as urea ( $\mathrm{pH} \mathrm{7.4),} \mathrm{mannitol} \mathrm{(pH} \mathrm{8.4)}$ and folate ( $\mathrm{pH} \mathrm{9),} \mathrm{also} \mathrm{resulted} \mathrm{in} \mathrm{lengthened}$ duration of nerve blocks. ${ }^{8}$ These observations led to the suggestion that the relative alkalinity, rather than the dextran, was the determining factor in the alteration of action of bupivacaine.

Galindo and Witcher ${ }^{9}$ confirmed this observation in vitro by adding sodium bicarbonate to a mixture of bupivacaine and 2-chloroprocaine. The resultant elevation of the $\mathrm{pH}$ of the mixture, from 3.6 to 5.56, significantly delayed the regression of the block produced in a rat sciatic nerve preparation. Galindo ${ }^{10}$ subsequently reported an in vivo study in which the $\mathrm{pH}$ of local anaesthetic agents (bupivacaine, mepivacaine and lidocaine) had been adjusted to 7.0 and 7.4 by addition of sodium bicarbonate, prior to regional anaesthesia (including epidural anaesthesia). This $\mathrm{pH}$ adjustment was associated with consistent improvement in the quality and duration of block and lower plasma drug levels, as compared with commercial local anaesthetic preparations. 
The intent of the present study was to assess the clinical effects (onset time, duration of block and plasma drug levels) of raising the $\mathrm{pH}$ (from a mean of 5.65 to 7.26) of 0.25 per cent bupivacaine $\left(2.5 \mathrm{mg} \cdot \mathrm{m}^{-1}\right)$, immediately prior to injection of the drug into the epidural space, for analgesia during the first stage of labour.

\section{Methods}

Following the approval of the Clinical Screening Committee for Research Involving Human Subjects of the University of British Columbia, informed consent was obtained from parturients who requested epidural analgesia during the first stage of labour. An epidural catheter was inserted at $\mathrm{L}_{2-3}$ or $\mathrm{L}_{3 \rightarrow}$ level and either the standard formulation of bupivacaine 0.25 per cent (Marcaine ${ }^{8}$ ), or its $\mathrm{pH}$-adjusted counterpart, was injected in a doubleblind manner. The $\mathrm{pH}$ of the formulations was measured within 30 minutes of preparation, using a digital $\mathrm{pH}$ meter with a combination electrode with a calomel reference. The $\mathrm{pH}$-adjusted bupivacaine was freshly prepared, immediately prior to injection, by the addition of $0.1 \mathrm{ml}$ of 8.4 per cent (wt/vol) sodium bicarbonate to $20 \mathrm{ml}$ of $0.25 \mathrm{per}$ cent bupivacaine, using a tuberculin syringe and a \#25 gauge needle. The bupivacaine-bicarbonate mixture was inverted, without shaking, a number of times to promote thorough mixing. No precipitate was observed in any preparation.

Sixty ASA physical status I or II parturients in established, uncomplicated labour were randomly assigned to one of two groups, to receive an initial epidural injection of either $8 \mathrm{ml}$ of $\mathrm{pH}$-adjusted 0.25 per cent bupivacaine or $8 \mathrm{ml}$ of the standard commercial preparation of 0.25 per cent bupivacaine. The drug was injected in two fractions of $4 \mathrm{ml}$ each, one minute apart. No epinephrine was used as a "test dose" because it was felt that this might affect both onset time and duration of the block.

Parturients who had experienced complications of pregnancy or labour, or who declined to participate, were excluded from the study. Both the patient and the investigator making the observations were blinded to the $\mathrm{pH}$ of the drug administered. The following information was recorded:

Study population

Age, height, weight, parity.

\section{Drug effect}

Time of initial injection, time of onset of sensory block (loss of temperature sensation to ice at $T_{12}-L_{1}$ level), time to peak effect (first painless contraction), upper limit of spread (two consecutive identical segmental observations of loss of temperature sensation to ice), duration of block (time to first request for re-injection), maternal plasma bupivacaine levels (15 minutes after initial injection), $\mathrm{pH}$ of bupivacaine solution.

\section{Drug analysis}

Maternal plasma bupivacaine (free base) levels were measured with slight modification of the method of Lesko et al. ${ }^{11}$

A capillary gas-liquid chromatograph (GLC) (Varian Aerograph model 3700) equipped with a nitrogen-phosphorus detector and fused silica DB-1 capillary column $(0.2 \mathrm{~mm}$ ID $\times 15 \mathrm{~m}, \mathrm{~J}$ and $\mathrm{W}$ Scientific) was operated in the split mode (25:1) configuration. Duplicate measurements were performed on all samples with a resulting coefficient of variation of five per cent or less.

\section{Statistical analysis}

Data were analyzed using the Student's t-test. A p value $<0.05$ was considered statistically significant.

\section{Results}

The patients in both the $\mathrm{pH}$-adjusted group and the control group were comparable, as regards age, height, weight and parity (Table I).

The mean $\mathrm{pH}$ of the commercial 0.25 per cent bupivacaine preparation was 5.65 , while that of the $\mathrm{pH}$-adjusted group was 7.26 (Table II). The differences in onset times ( 3.2 minutes vs 6.0 minutes) and the time to first re-injection (96.5 minutes vs 79.4 minutes) for the $\mathrm{pH}$-adjusted group and control group, respectively, were statistically significant. ( $p<0.001$ for onset time and $p<0.02$ for duration.) Adjustment of the $\mathrm{pH}$ had no significant effect on the time to peak effect (Table II).

The upper segmental level of the block ranged from $T_{11}$ to $T_{5}$, with no difference between the groups.

Mean maternal plasma drug levels were 0.342 $\mu \mathrm{g} \cdot \mathrm{ml}^{-1}$ in the $\mathrm{pH}$-adjusted group and 0.344 $\mu \mathrm{g} \cdot \mathrm{ml}^{-1}$ in the control group (Table II). This difference was not statistically significant. 
TABLE I Study population mean (range)

\begin{tabular}{lll}
\hline & $\begin{array}{l}\text { pH-adjusted } \\
\text { bupivacaine } \\
(n=30)\end{array}$ & $\begin{array}{l}\text { Standard } \\
\text { bupivacaine } \\
(n=30)\end{array}$ \\
\hline Age (years) & $27.4(20-34)$ & $26.5(19-40)$ \\
Height (cm) & $163(157-178)$ & $161(150-178)$ \\
Weight (kg) & $71.75(58.2-95.4)$ & $67.9(54-97.7)$ \\
Parity-nulliparas & 24 & 21 \\
$\quad$-multiparas & 6 & 9 \\
\hline
\end{tabular}

There was no apparent motor blockade in any patient in either group, nor any difference in incidence of side-effects.

\section{Discussion}

In 1910, Lawen ${ }^{12}$ published his observation that the addition of 0.5 per cent sodium bicarbonate to one per cent procaine "showed an increased potency.' He also noted that if the procaine bicarbonate was boiled prior to use, the potency was further increased. He postulated that boiling the solution would free carbon dioxide, converting a fraction of the bicarbonate to carbonate, with an increase in the basic form of novocain. Lawen referred to a previous study, which reported similar effects of addition of sodium bicarbonate to a local anaesthetic solution.

It is well recognised that local anaesthetic solutions maintain a ratio between the uncharged (un-ionized) form and the charged cationic form; and that this ratio will vary with the $\mathrm{pH}$ of the solution. There is a specific hydrogen ion concentration (pH), known as the $\mathrm{pKa}$, for each local anaesthetic drug, at which the concentration of the uncharged base is equal to the concentration of the

TABLE II Clinical effect of pH-adjustment of $0.25 \%$ bupivacaine mean ( \pm SEM)

\begin{tabular}{|c|c|c|}
\hline & $\begin{array}{l}\text { pH-adjusted } \\
\text { bupivacaine } \\
(n=30)\end{array}$ & $\begin{array}{l}\text { Standard } \\
\text { bupivacaine } \\
(n=30)\end{array}$ \\
\hline pH & $7.26( \pm 0.34)^{*}$ & $5.65( \pm 0.07)$ \\
\hline Onset time (minutes) & $3.2( \pm 0.24)^{*}$ & $6.0( \pm 0.53)$ \\
\hline Time to re-injection (minutes) & $96.5( \pm 5.24)^{* *}$ & $79.4( \pm 4.39)$ \\
\hline Time to peak effect (minutes) & $14.2( \pm 1.1)$ & $16.5( \pm 1.15)$ \\
\hline $\begin{array}{l}\text { Maternal drug levels }\left(\mu \mathrm{g} \cdot \mathrm{ml}^{-1}\right) \\
\text { (15 minutes after injection) }\end{array}$ & & $0.344 \pm 0.07$ \\
\hline
\end{tabular}

*Significant $-p<0.001$.

**Significant $-\mathrm{p}<0.02$ charged cationic form. For bupivacaine, the pKa has been determined in vitro as being 8.01. ${ }^{13}$ As the $\mathrm{pH}$ is lowered (increase in hydrogen ion concentration) there will be more charged cations in solution and conversely, as the $\mathrm{pH}$ increases, relatively more of the local anaesthetic drug will exist in the free base form.

Most local anaesthetic agents are marketed as mildly acidic hydrochloride salts, to improve solubility. When injected, they are buffered in the body tissues to the physiological $\mathrm{pH}$, with a consequent increase in the amount of uncharged base available for diffusion through axonal membranes. Ritchie et al. ${ }^{14,15}$ used an isolated rabbit vagus nerve preparation to show that, in the presence of an intact nerve sheath, the rate of onset of nerve block was more rapid when the bathing medium was made more alkaline. However, when the nerve was desheathed, the more acidic solutions (with greater amounts of charged cation) had increased local anaesthetic activity. They postulated that the uncharged base form is more soluble in connective tissue than the cationic form and more readily and rapdily diffuses through the nerve sheath. Once this diffusion has occurred, it is the positively charged cation that binds to the receptor sites and blocks nerve conduction. ${ }^{13}$

Knowing that the pKa of bupivacaine is 8.01 , it can be calculated, using the Henderson-Hasselbalch equation, that approximately 16 per cent of the drug will be in the form of the base at $\mathrm{pH} 7.2$. When the $\mathrm{pH}$ is lowered to 5.5 , the proportion of the basic form will decrease to less than one per cent. Moore $^{16}$ reported that commercially supplied 0.25 per cent bupivacaine has a $\mathrm{pH}$ of 5.72 , while this study reports a mean $\mathrm{pH}$ of 5.65 . Addition of $0.1 \mathrm{ml}$ of 8.4 per cent sodium bicarbonate consistently raised the $\mathrm{pH}$ of the solution to a mean of 7.26 , with a calculated increase in the proportion of uncharged base to greater than 16 per cent.

The time of onset of analgesia was significantly shortened from 6.0 minutes to 3.2 minutes by this $\mathrm{pH}$ adjustment ( $\mathrm{p}<0.001$ ). It is felt that this difference is also clinically significant, in that many parturients will obtain pain relief in little more than half the usual time. Perhaps of greater clinical importance is the increased duration of analgesia, from 79 minutes to 97 minutes. During a long labour, with multiple, repeat epidural injections, the longer interval between these doses would result 
in a significant reduction in the total dose of bupivacaine used. In spite of the increased rate of onset of analgesia, $\mathrm{pH}$ adjustment of the bupivacaine to 7.26 did not significantly affect the time to peak effect of the drug (as determined by the first painless contraction). This contrasts with the shortened time to peak effect reported by Galindo, using $20 \mathrm{ml}$ doses of 0.5 per cent bupivacaine..$^{10}$ The difference is probably related to the relatively low, analgesic dose of bupivacaine used in this study as compared with the larger $(100 \mathrm{mg})$, anaesthetic dose used by Galindo.

Appleyard et al. ${ }^{17}$ reported peak bupivacaine levels 16 minutes after epidural injection of 1.5 $\mathrm{mg} \cdot \mathrm{kg}^{-1}$ of 0.5 per cent bupivacaine. On the basis of their findings, it was elected to measure maternal plasma bupivacaine levels 15 minutes after epidural injection of the drug. Recently, Thompson et al. ${ }^{18}$ reported very much longer times to peak maternal blood bupivacaine levels (from 32 to 51 minutes). A number of factors probably influence the speed of absorption of bupivacaine from the epidural space. These include the concentration of the drug, the total dose and the speed of injection. In this study, the maternal blood samples were all drawn at the same time interval after epidural injection and, for this reason, it is felt that comparison of the two groups is valid. There was no statistically significant effect on maternal plasma drug level observed, as a result of raising the $\mathrm{pH}$ of the bupivacaine prior to epidural injection. This was possibly due to the low bupivacaine dose $(20 \mathrm{mg})$ administered. Larger, anaesthetic doses may produce a different result.

In conclusion, this study has demonstrated that raising the $\mathrm{pH}$ of 0.25 per cent bupivacaine from 5.65 to 7.26 , immediately prior to epidural injection during labour, will significantly increase the speed of onset and duration of analgesia. However, the time to reach peak effect and the maternal plasma bupivacaine levels appear to be unaffected. During active labour the rapid onset time will be appreciated by parturients, even if the time to complete pain relief appears to be unaltered at these low bupivacaine doses. The prolonged duration of action will reduce the number of calls for reinjection of the epidural catheter, in a long labour, with consequent reduction of the total dose administered. It would appear that routine adjustment of the
pH of bupivacaine to about seven, during labour, offers significant clinical advantages.

\section{References}

1 Loder RE. A local anaesthetic solution with longer action. Lancet 1960; 2:346-7.

2 Chinn MA, Wirjoatmadja K. Prolonged local anaesthesia. Lancet 1967; 2:835.

3 Kaplan JA, Miller ED, Gallagher EG. Postoperative analgesia for thoractomy patients. Anesth Analg 1975; $54: 773-7$.

4 Bridenbaugh $L D$. Does the addition of low molecular weight dextran prolong the duration of action of bupivacaine? Regional Anesthesia 1978; 3:6-7.

5 Scurlock JE, Curtiss BM. Dextran - local anesthetic interactions. Anesth Analg 1980; 59: 335-6.

6 Buckley FP, Fink BR. Duration of action of nerve blocks produced by mixtures of local anesthetics and low molecular weight dextran: studies in rat infraorbital nerve blocks. Anesth Analg 1981; 60: 142-5.

7 Rosenblatt $R M$, Fung $D L$. Mechanism of action for dextran prolonging regional anesthesia. Regional Anesthesia 1980; 5: 3-5.

8 Rosenblatt $R$. Dextran as a local anesthetic adjuvant: its history and current status. Regional Anesthesia 1981; 6: 108-11.

9 Galindo A, Witcher T. Mixtures of local anesthetics: bupivacaine-chloroprocaine. Anesth Analg 1980; 59: 683-5.

10 Galindo A. pH-adjusted local anesthetics: clinical experience. Regional Anesthesia 1983; 8: 35-6.

11 Lesko L, Ericson J, Ostheimer G, Marion A. Simultaneous determination of bupivacaine and 2,6pipecoloxyledide in serum by gas-liquid chromatography. J Chromatogr 1980; 182: 226-31.

12 Lawen $A$. Ueber die verwendung des novokains in natriumbikarbonat - kochsolzlosungen zur lokalen anaesthesie. Muenchener Medizinsche Wochenschrift 1910; 57: 2044-6.

13 Cousins MJ, Bridenbaugh PO. Neural Blockade. Philadelphia: J.B. Lippincott, 1980.

14 Ritchie JM, Ritchie B, Greengard $P$. The active structure of local anesthetics. J Pharmacol Exp Ther 1965; 150: 152.

15 Ritchie JM, Ritchie $B$, Greengard $P$. The effect of the nerve sheath on the action of local anesthetics. $J$ Pharmacol Exp Ther 1965; 150: 160.

16 Moore $D C$. The $\mathrm{pH}$ of local anaesthetic solutions. Anesth Analg 1981; 60: 833-4. 
17 Appleyard TN, Witt A, Atkinson RE, Nicholls ADG. Bupivacaine carbonate and bupivacaine hydrochloride: a comparison of blood concentrations during epidural blockade for vaginal surgery. $\mathrm{Br} \mathrm{J}$ Anaesth 1974; 46: 530-3.

18 Thompson EM, Wilson CM, Moore J, McClean E. Plasma bupivacaine levels associated with extradural anaesthesia for Caesarean section. Anaesthesia 1985; 40: 427-32.
Résumé

Des étude préliminaires ont rapporté que l'augmentation du $\mathrm{pH}$ des anesthésiques locaux est associée avec une amélioration de la qualité et de la durée du bloc. Cette étude investigue l' effet sur le début d' action et la durée de l'analgésie après ajustement du $\mathrm{pH}$ de 0.25 pour cent de bupivacaîne immédiatement avant l'injection dans l'espace épidural chez des femmes à terme. L'addition de $0.1 \mathrm{ml}$ de 8.4 pour cent de bicarbonate de soude a $20 \mathrm{ml}$ de 0.25 pour cent de bupivacaîne augmenta le $\mathrm{pH}$ de l'anesthésique local de 5.65 \& 7.26 (valeurs moyennes).

Trente parturientes ont reçu en injection épidurale $8 \mathrm{ml}$ de bupivacaine 0.25 pour cent à $\mathrm{pH}$ ajusté et un groupe contrôle de 30 parturientes a reçu $8 \mathrm{ml}$ de la solution commerciale standard de préparation de 0.25 pour cent de bupivacaîne. L'augmentation du $\mathrm{pH}$ de l'anesthésique local accéléra significativement le début de l'analgésie de 6.0 minutes a 3.2 minutes ainsi que la durée de l'analgésie qui augmenta significativement de $79.4 \mathrm{mi}$ nutes a 96.5 minutes. $I I n^{\prime} y$ avait aucune infuence significative sur le temps d' effet maximal ni sur le niveau plasmatique moyen maternel de bupivacaine. 